\title{
EFL Learners' Affect, Engagement, Misbehaviours, and Achievement: A Classroom Observation Perspective
}

\author{
Bo Yang ${ }^{1,2} \&$ Christo Moskovsky ${ }^{2}$ \\ ${ }^{1}$ Xinhua College, Ningxia University, Yinchuan, China \\ ${ }^{2}$ Faculty of Education and Arts, School of Humanities and Social Science, The University of Newcastle, New \\ South Wales, Australia \\ Correspondence: Christo Moskovsky, Faculty of Education and Arts, School of Humanities and Social Science, \\ The University of Newcastle, New South Wales, Australia. E-mail: christo.moskovsky@newcastle.edu.au
}

Received: April 8, $2021 \quad$ Accepted: May 19, $2021 \quad$ Online Published: June 7, 2021

doi:10.5539/ijel.v11n4p12 URL: https://doi.org/10.5539/ijel.v11n4p12

\begin{abstract}
Most previous research examining the correlation between affect and achievement of learners of English as a foreign language (EFL) has relied on questionnaire and/or interview data. The current study, conducted in a Chinese EFL context, chose to explore this relationship on the basis of quantitative and qualitative classroom observation data, with a special focus on learners' classroom engagement and misbehaviours. The participant sample involved the EFL learners and teachers in six classes at a key and a non-key university in Northwest China. Data in relation to participants' affect, engagement, and misbehaviours were collected via classroom observations, including some video-recording. The participating students' College English Test-Band 4 (CET-4) scores were used as a measurement of EFL achievement. Participants' affect, engagement, and achievement formed a reciprocal relationship; the latter was negatively connected with misbehavious. Rather than gender, type of school (key vs. non-key university) had significant effects on the variables being examined. Data revealed that teachers, peers, and classroom environment were also influential factors in explaining the differences in the relationship between the identified variables.
\end{abstract}

Keywords: EFL, affect, engagement, misbehaviours, achievement

\section{Introduction}

Cognition and affect are two inextricable components in language learning (Habrat, 2018). Typically relying on questionnaire and interview data, researchers have elucidated the correlation between language learners' affect and achievement (Clément et al., 1994; Dörnyei, 1994, 2005; Gardner, 1985; Horwitz, 2001; Horwitz et al., 1986). More recently, some scholars have provided a new dimension to relevant research by introducing the theory of engagement into general education (Carini et al., 2006; Fredricks, 2011). However, relatively little is known about the potential relationship between EFL learners' affect, engagement, and achievement. Employing the less commonly used method of classroom observation, this study was designed to quantitatively and qualitatively seek an in-depth understanding of the relationship between learners' affect, engagement, and achievement. A novel dimension involved an additional focus on student participants' classroom misbehaviours and their implications for achievement.

\section{Literature Review}

\subsection{Affect}

Affect, emotions, feelings, and moods are usually used synonymously (Arnold \& Brown, 1999). While emotions are defined as more fleeting and intense subjective reactions that direct towards a specific event with a clear referent, moods are referred to as longer lasting and less intense cognitive responses that predispose to no particular referent (Clore et al., 2001; Davidson, 1994; Rosenberg, 1998; Schwarz \& Clore, 1996). Affect is an umbrella concept that encompasses a broad range of emotions, feelings, and moods (Clore et al., 2001). Arnold and Brown (1999) classified affect in language learning into two major categories. One category is concerned with internal factors that are parts of learners' personalities, including attitudes, motivation, anxiety, self-esteem, inhibition, extroversion and introversion, dignity, and so forth. The other category focuses on relational factors or the influence of learners as participants in a socio-cultural situation, where learners inevitably relate to others. 
This category takes learners' empathy, classroom interactions, and cross-cultural processes into consideration. Oxford (1990) asserted that learners' internal affective variables mostly determine success or failure in language learning. Among learners' internal factors, attitudes (Dörnyei \& Clément, 2001; Gardner \& MacIntyre, 1993), motivation (Gardner, 1985; Gardner \& MacIntyre, 1993), anxiety (Horwitz et al., 1986; Onwuegbuzie et al., 2000), and self-esteem (Habrat, 2018; Liu \& Zhang, 2008) have extensively proven to be significant predictors of language achievement. Within the already considerable body of research on the relationship between learners' affect and achievement, relatively little attention has been devoted to the link between affect and engagement, despite the fact that learners' affective variables, such as motivation and anxiety, exert substantial influence on engagement (Oxford, 1990; Ryan \& Deci, 2000).

\subsection{Engagement}

According to Astin (1984), engagement is "the amount of physical and psychological energy that the student devotes to the academic experience" (p. 297). Astin (1984) highlighted the behavioural aspect of his engagement theory and stated that students who expend considerable time and energy on their studies are usually active in school and have more interactions with their teachers and peers. Much research in general education has demonstrated that engagement is a potent predictor of learning outcomes (Carini et al., 2006; Fredricks, 2011). However, few studies have uncovered the link between EFL learners' engagement and their affect and achievement, particularly in a Chinese context.

\subsection{Achievement}

Achievement narrowly refers to performance in standardised achievement tests (Simpson \& Weiner, 1989). In a broad sense, achievement is the measurement of general academic outcomes, such as grade point average (GPA), academic persistence, and school-related attitudes (Genesee et al., 2005).

\subsection{Misbehaviours}

Türnüklü and Galton (2001) defined classroom misbehaviours as any behaviours that imperil students' academic performance during class. Research has found that classroom misbehaviour is an indicator of depressed achievement (Deniz \& Chockalingam, 2003; Khoo \& Oakes, 2003). While classroom misbehaviours are widely explored in general education, few studies have specifically focused on the EFL context (Debreli \& Ishanova, 2019).

\section{Research Objectives}

The present study intended to pursue the following research objectives:

(1) To examine the levels of Chinese undergraduate EFL learners' affect, engagement, misbehaviours, and achievement and whether these variables are influenced by gender and/or school differences;

(2) To establish the relationship between student participants' affect, engagement, misbehaviours, and achievement;

(3) To identify the factors determining the differences in the identified variables and influencing the relationships among them.

\section{Method}

\subsection{Participants}

To enhance the representativeness of the participant sample, six participating EFL teachers at a key university and a non-key university encouraged their non-English major students in six classes who took the College English course in four 45-minute lessons per week and who were involved in the previous questionnaire survey to participate in the classroom observations. Participating students agreed to be observed and 30 of them (five students per class), included 15 students (Male=5, Female $=10$ ) from the key university and another 15 students (Male=7, Female $=8$ ) from the non-key university, agreed to be video-recorded during their English classes.

\subsection{Instrument}

According to Bailey (2001), classroom observation is "the purposeful examination of teaching and/or learning events through the systematic processes of data collection and analysis" (p. 114). Departing from most previous research on the relationship between EFL learners' affect and achievement which generally relied on questionnaires or interviews, this study attempted to pursue the research objectives via classroom observations.

\subsection{Data Collection}

Observation data were in part collected via video-recording the selected student participants during their English 
classes. To protect the privacy and anonymity of other students and the teachers, the five student participants in each class were asked to sit together for a partial video record. The video camera, positioned on a tripod in front, was set up to capture only these students, while the English teachers and the remaining students did not appear on camera. To minimise disruption of classroom routines, the researchers implemented non-participant observation, sitting at the back of the classroom and completing the observation records.

To objectively and accurately evaluate non-English majors' ability in listening, writing, reading, and translation, the CET-4 was first administered in June 1987. Since then, millions of undergraduates in China have participated in the test, making the CET-4 the largest national English examination worldwide (Jin \& Yang, 2006). Owing to the universality, reliability, and predictability of the test (Jin \& Yang, 2006), participating students' CET-4 scores were collected to measure their learning achievement before the actual observations.

\subsection{Data Analysis}

The video-recorded classroom observation enabled the researchers to play and replay video clips concerning particular behaviours when coding was in doubt and to analyse data in a more flexible and in-depth way (Croll, 1986), guaranteeing the reliability and validity of this study. Data analysis was based on a mixture of quantitative and qualitative techniques, deploying NVivo 12 Plus and SPSS 25.0 as data analysis tools. The quantitative analysis focused on systematic observation using coding schemes to present the frequency and relationship between particular classroom activities (Wragg, 2012). Drawing on the Flanders Interaction Analysis System (Flanders, 1970), a designated coding system for classroom observation was constructed. Each classroom observation video file (altogether 30 files) was divided into three-second clips. Each video clip was then coded according to the constructed coding system. This enabled us to assemble a number of coding references for each participant. The interplay among participants' affect, engagement, and misbehaviours was examined and visualised via NVivo software. Finally, the number of coding references for each participant and the CET-4 scores were input into SPSS for independent t-tests and correlation analysis.

Qualitative analyses of the observation data were conducted to probe beneath the surface of classroom activities and elicit their true meaning, as well as their effects on teaching and learning (Croll, 1986).

\section{Quantitative Results}

\subsection{Coding}

Nunan (1992) summarised four major methods of classroom observation and research: formal experiment, stimulated recall, observation schemes, and interaction analysis. The present study considers English classroom teaching and learning as an interaction between the teacher and students. Regarding classroom interaction analysis, the Flanders Interaction Analysis System (FIAS) (Flanders, 1970) has frequently been utilised in research (Ritson et al., 1982). Flanders (1970) collected each behavioural sample from classroom observation every three seconds and then coded it. Based on the time sequence of the classroom instruction, these codes are connected into a time series, which presents the basic structure and behaviour pattern of the classroom teaching as a matrix. Inspired by the FIAS (Flanders, 1970), the current study divided each video file into three-second video clips and constructed a coding system focusing on student participants' affect, engagement, and misbehaviours (see Table 1). Student participants' verbal and non-verbal acts were constructed to interpret engagement. The coding system of student participants' affect was constructed on the basis of their engagement and misbehaviours; it identified four affective variables: positive attitudes, negative attitudes, anxiety, and positive self-esteem. Student participants' inattentiveness, chatting with classmates, sleeping, playing with smartphones, and/or engaging in activities unrelated to class were coded as misbehaviours. 
Table 1. Coding system for the classroom observation

\begin{tabular}{|c|c|c|c|}
\hline Classification & & Coding & Content \\
\hline \multirow[t]{4}{*}{ Affect during the English class } & & 1 & Positive attitudes \\
\hline & & 2 & Negative attitudes \\
\hline & & 3 & Anxiety \\
\hline & & 4 & Positive self-esteem \\
\hline \multirow[t]{9}{*}{ Engagement during the English class } & Verbal acts & 5 & Passively answering questions \\
\hline & & 6 & Actively answering questions \\
\hline & & 7 & Actively asking questions \\
\hline & & 8 & Discussing with classmates \\
\hline & Non-verbal acts & 9 & Listening to instruction \\
\hline & & 10 & Taking notes \\
\hline & & 11 & Thinking \\
\hline & & 12 & Doing practice \\
\hline & & 13 & Refusing to discuss with classmates \\
\hline \multirow[t]{5}{*}{ Misbehaviours during the English class } & & 14 & Inattentiveness \\
\hline & & 15 & Chatting with classmates \\
\hline & & 16 & Playing with the smartphone \\
\hline & & 17 & Sleeping \\
\hline & & 18 & Engaging in activities unrelated to class \\
\hline
\end{tabular}

\subsection{Comparison of Student Participants' Achievement Across Gender and School}

All 30 student participants' CET-4 scores were subjected to independent t-tests across gender and school. The results in Table 2 demonstrated that type of school significantly influenced student participants' CET-4 scores $(\mathrm{df}=28, \mathrm{t}=4.542, \mathrm{p}<.001)$, with key university participants having a higher level of learning achievement than their peers at the non-key university. Gender, on the other hand, did not show significant effects on the variables under investigation $(\mathrm{df}=28, \mathrm{t}=-1.393, \mathrm{p}=.175)$.

Table 2. Independent t-tests of achievement across gender and school

\begin{tabular}{llllll}
\hline & MM & SDM & df & t & Sig. \\
\cline { 2 - 5 } MF & SDF & & -1.393 & .175 \\
Achievement & 428.25 & 59.61 & 28 & & \\
& 454.33 & 43.13 & & & Sig. \\
& M1 & SD1 & & t & .000 \\
& M2 & SD2 & df & t & \\
\hline
\end{tabular}

Note. $\mathrm{MM}=$ mean scores of male; $\mathrm{MF}=$ mean scores of female; $\mathrm{SDM}=$ standard deviation of male; $\mathrm{SDF}=$ standard deviation of female; M1=mean scores of the key university; M2=mean scores of the non-key university; SD1=standard deviation of the key university; $\mathrm{SD} 2=$ standard deviation of the non-key university; $\mathrm{df}=$ degree of freedom; $\mathrm{t}=\mathrm{t}$-value; Sig. $=$ significant.

\subsection{Comparison of Affect, Engagement, and Misbehaviours Based on Gender}

As shown in Table 3, among all coding references regarding student participants' affect, positive attitudes, negative attitudes, and positive self-esteem were the top three factors for both male and female participants. Both male and female participants reported more positive attitudes towards English learning. In comparison, only a small number of references relating to student participants' anxiety were recorded. 
Table 3. Comparison of affect, engagement, and misbehaviours across gender

\begin{tabular}{lll}
\hline Affect & Male & Female \\
\hline Positive attitudes & $82.05 \%$ & $85.25 \%$ \\
Negative attitudes & $9.25 \%$ & $5.72 \%$ \\
Anxiety & $1.67 \%$ & $0.8 \%$ \\
Positive self-esteem & $7.02 \%$ & $8.23 \%$ \\
\hline Engagement & Male & Female \\
\hline Verbal acts & & \\
Passively answering questions & $0.06 \%$ & $0.03 \%$ \\
Actively answering questions & $4.12 \%$ & $5.3 \%$ \\
Actively asking questions & $0 \%$ & $0 \%$ \\
Discussing with classrooms & $4.21 \%$ & $4.26 \%$ \\
Non-verbal acts & & \\
Listening to instruction & $72.78 \%$ & $72.12 \%$ \\
Taking notes & $4.8 \%$ & $5.36 \%$ \\
Thinking & $1.71 \%$ & $2.33 \%$ \\
Doing practice & $10.39 \%$ & $9.69 \%$ \\
Refusing to discuss with classmates & $1.93 \%$ & $0.9 \%$ \\
\hline Misbehaviours & Male & Female \\
\hline Inattentiveness & $60.72 \%$ & $12.5 \%$ \\
Chatting with classmates & $3.52 \%$ & $47.47 \%$ \\
Playing with the smartphone & $4.97 \%$ & $1.69 \%$ \\
Sleeping & $7.47 \%$ & $0 \%$ \\
Engaging in activities unrelated to class & $23.31 \%$ & $38.34 \%$ \\
\hline
\end{tabular}

Regarding engagement, for male participants, only $4.12 \%$ of all recorded nodes were related to their actively answering questions, while the proportion for female participants was $5.3 \%$. Nodes related to discussing with classmates also accounted for a small percentage: $4.21 \%$ and $4.26 \%$ for male and female participants, respectively. Both male $(0.06 \%)$ and female $(0.03 \%)$ participants generally avoided passive answering of questions. Remarkably, the observation did not capture even a single node denoting male or female participants' willingness to actively ask questions.

As Table 3 reveals, a lot more nodes denoting non-verbal acts were recorded. For both male and female participants, listening to instruction $(72.78 \%$ and $72.12 \%$, respectively) occupied most of the learning process, followed by doing practice, $10.39 \%$ (male) and $9.69 \%$ (female). Nodes denoting taking notes and thinking made up a smaller proportion of participants' non-verbal acts.

Both male and female participants engaged in misbehaviours during their English classes. Compared with female participants $(12.5 \%)$, male participants were much more likely to be inattentive $(60.72 \%)$. Among the male group, other misbehaviours involved unrelated activities (23.31\%), sleeping (7.47\%), playing with the smartphone $(4.97 \%)$, and chatting with classmates $(3.52 \%)$. Chatting with classmates comprised a relatively large proportion of female students' misbehaviours $(47.47 \%)$. Other misbehaviours within the female group involved unrelated activities (38.34\%), inattentiveness (12.5\%), and playing with the smartphone (1.69\%). No female participants were observed asleep in class.

The effects of gender on student participants' affect, engagement, and misbehaviours were further examined by independent t-test. Nodes regarding negative attitudes and anxiety as well as passively answering questions and refusing to discuss with classmates were reversely coded in computing the indices of affect and engagement. The results in Table 4 indicated that gender was not a statistically significant determinant of participants' affect $(\mathrm{df}=28, \mathrm{t}=-1.313, \mathrm{p}=.200)$, engagement $(\mathrm{df}=28, \mathrm{t}=-1.143, \mathrm{p}=.263)$, and misbehaviours $(\mathrm{df}=28, \mathrm{t}=1.615, \mathrm{p}=.118)$. 
Table 4. Independent t-test of affect, engagement, and misbehaviours across gender

\begin{tabular}{llllll}
\hline & MM & SDM & & & Sig. \\
\cline { 2 - 4 } Affect & MF & SDF & df & t & .200 \\
Engagement & 169.67 & 88.85 & 28 & -1.313 & .263 \\
& 205.89 & 62.61 & & & \\
Misbehaviours & 80.92 & 17.97 & 28 & -1.143 & .118 \\
& 87.85 & 15.08 & & & 1.615 \\
\hline
\end{tabular}

Note. $\mathrm{MM}=$ mean scores of male; $\mathrm{MF}=$ mean scores of female; $\mathrm{SDM}=$ standard deviation of male; $\mathrm{SDF}=$ standard deviation of female; $\mathrm{df}=$ degree of freedom; $\mathrm{t}=\mathrm{t}$-value; Sig. $=$ significant.

\subsection{Comparison of Affect, Engagement, and Misbehaviours Based on School}

As shown in Table 5, all student participants displayed highly positive attitudes towards English learning, with key university participants only slightly outranking their non-key university peers $(85.1 \%$ and $82.96 \%$, respectively). Notably, negative attitudes towards English learning were much more prevalent among the non-key than key university participants (13.03\% and $1.17 \%$, respectively). Another substantial difference based on type of school was found in relation to positive self-esteem: $13.73 \%$ among the key university student participants and only $1.73 \%$ among the non-key university participants. A notable finding concerns the almost complete absence of anxiety in the whole sample: none in key university participants and only $2.28 \%$ in non-key university participants.

Table 5. Comparison of affect, engagement, and misbehaviours across school

\begin{tabular}{lll}
\hline Affect & Key university & Non-key university \\
\hline Positive attitudes & $85.1 \%$ & $82.96 \%$ \\
Negative attitudes & $1.17 \%$ & $13.03 \%$ \\
Anxiety & $0 \%$ & $2.28 \%$ \\
Positive self-esteem & $13.73 \%$ & $1.73 \%$ \\
\hline Engagement & Key university & Non-key university \\
\hline Verbal acts & & \\
Passively answering questions & $0 \%$ & $0.08 \%$ \\
Actively answering questions & $8.26 \%$ & $1.36 \%$ \\
Actively asking questions & $0 \%$ & $0 \%$ \\
Discussing with classrooms & $7.81 \%$ & $0.67 \%$ \\
Non-verbal acts & & \\
Listening to instruction & $72.18 \%$ & $72.63 \%$ \\
Taking notes & $4.12 \%$ & $6.17 \%$ \\
Thinking & $3.61 \%$ & $0.57 \%$ \\
Doing practice & $4.01 \%$ & $15.92 \%$ \\
Refusing to discuss with classmates & $0 \%$ & $2.59 \%$ \\
\hline Misbehaviours & Key university & Non-key university \\
\hline Inattentiveness & $5.56 \%$ & $39.34 \%$ \\
Chatting with classmates & $29.63 \%$ & $25.71 \%$ \\
Playing with the smartphone & $0 \%$ & $3.65 \%$ \\
Sleeping & $0 \%$ & $4.04 \%$ \\
Engaging in activities unrelated to class & $64.81 \%$ & $27.27 \%$ \\
\hline
\end{tabular}

In terms of student participants' verbal acts, $8.26 \%$ and $7.81 \%$ of the nodes were related to their initiative to answer questions and willingness to discuss with classmates at the key university. The values for these two only stood at $1.36 \%$ and $0.67 \%$ at the non-key university. Accounting for $0.08 \%$, the node of passively answering questions was only recorded among the non-key university participants. No participants at either university were observed to actively ask questions during their English classes.

The nodes denoting non-verbal acts again considerably exceeded the verbal ones across the whole sample. Listening to instruction represented the highest proportion of the non-verbal nodes $(72.18 \%$ key university and $72.63 \%$ non-key university). Non-key university participants spent more time doing practice $(15.92 \%)$ than their counterparts at the key university (4.01\%). In addition, non-key university participants took longer to take notes 
during the English class (6.17\%) than their key university peers (4.12\%). In contrast, key university participants spent more time on thinking (3.61\%) than their peers at the non-key university $(0.57 \%)$.

Table 5 demonstrates that engaging in activities unrelated to learning $(64.81 \%)$ and chatting with classmates (29.63\%) were major misbehaviours among the key university participants, but relatively few of them were inattentive (5.56\%). No coding reference was recorded for playing with the smartphone or sleeping during class. By comparison, at the non-key university, inattentiveness came up as a major misbehaviour $(39.34 \%)$, with unavoidable consequences for participants' learning. Unrelated activities $(27.27 \%)$ and chatting with classmates $(25.71 \%)$ also featured quite prominently among the non-key university participants. A smaller number of non-key university participants slept (4.04\%) or played with their smartphones (3.65\%) during the English class.

An independent t-test was conducted and the results in Table 6 verified the significant effects of school on student participants' affect $(\mathrm{df}=28, \mathrm{t}=5.463, \mathrm{p}<.001)$, engagement $(\mathrm{df}=28, \mathrm{t}=4.771, \mathrm{p}<.001)$, and misbehaviours $(\mathrm{df}=28, \mathrm{t}=-3.198, \mathrm{p}<.01)$.

Table 6. Independent t-test of affect, engagement, and misbehaviours across school

\begin{tabular}{llllll}
\hline & M1 & SD1 & & & Sig. \\
\cline { 2 - 3 } & M2 & SD2 & df & t & .000 \\
Affect & 244.33 & 9.23 & 28 & 5.463 & \\
Engagement & 138.47 & 74.49 & & & .000 \\
Misbehaviours & 95.84 & 1.98 & 28 & 4.771 & .003 \\
& 74.30 & 17.37 & & -3.198 & \\
\hline
\end{tabular}

Note. M1=mean scores of the key university; M2=mean scores of the non-key university; SD1=standard deviation of the key university; $\mathrm{SD} 2=$ standard deviation of the non-key university; $\mathrm{df}=$ degree of freedom; $\mathrm{t}=\mathrm{t}$-value; Sig. $=$ significant.

\subsection{Correlation Between Affect, Engagement, Misbehaviours, and Achievement}

Student participants' four affective variables recorded in the classroom observation could be further classified into two dimensions: positive affect including positive attitudes and positive self-esteem, and negative affect consisting of negative attitudes and anxiety. The coding references regarding student participants' affect including positive and negative affect, engagement, and misbehaviours were calculated and then correlation analysis was conducted with their achievement.

Table 7 reveals that student participants' affect, engagement, misbehaviours, and achievement formed significant correlations. Specifically, student participants' positive affect was positively related to active classroom engagement and achievement but negatively connected with misbehaviours, indicating that student participants who had a higher level of positive affect tended to have higher levels of engagement and achievement and a lower level of misbehaviours. In contrast, student participants' negative affect formed negative relationships with engagement and achievement but a positive correlation with misbehaviours, suggesting that student participants who had a higher level of negative affect were less likely to participate in classroom activities and have higher achievement but were more likely to misbehave during class.

Table 7. Correlation between affect, engagement, misbehaviours, and achievement

\begin{tabular}{|c|c|c|c|c|c|c|}
\hline & 1 & 2 & 3 & 4 & 5 & 6 \\
\hline Affect & - & & & & & \\
\hline Positive affect & $.978^{* *}$ & - & & & & \\
\hline Negative affect & $-.947^{* *}$ & $-.859^{* *}$ & - & & & \\
\hline Engagement & $.980^{* *}$ & $.969^{* *}$ & $-.913^{* *}$ & - & & \\
\hline Misbehaviours & $-.935^{* *}$ & $-.854^{* *}$ & $.978^{* *}$ & $-.903^{* *}$ & - & \\
\hline Achievement & $.872^{* *}$ & $.848^{* *}$ & $-.834^{* *}$ & $.861^{* *}$ & $-.837^{* *}$ & - \\
\hline
\end{tabular}

\section{Qualitative Results}

All 30 video-observed student participants were members of their classes and, therefore, unavoidably influenced by their teachers, peers, and the broader classroom environment. The qualitative dimension of the classroom 
observation examined the whole sample - the six English teachers and their whole classes - to reinforce the understanding of the relationship between the identified variables. The qualitative observation data included careful spot observation notes and repeated post-observation reviews of the video files.

\subsection{Traditional Classroom Setting}

All six investigated classes had a traditional classroom arrangement where the teacher carried out the instruction in the front of the classroom. The large class sizes (48-60 students) suppressed student-to-student discussions and also made it hard for teachers to move from their tables to interact with students or to control students' classroom behaviours, unavoidably reducing the effectiveness of teaching and learning.

\subsection{Teaching Methods}

Based on careful observation, two types of teaching methods were identified: teacher-centred and student-centred models.

\subsubsection{Teacher-Centred Model}

Consistent with traditional teaching methods, all three participating teachers at the non-key university employed the teacher-centred model in their class. To be more specific, these teachers directly began their instruction without any greetings or lead-in activities, with no obvious attempt to arouse students' learning interest at the beginning of the class. During the whole instruction, these three teachers kept standing on the platform and served as "broadcasters" in delivering their lessons to students. Their instruction mainly focused on translating important words, phrases, and sentences, failing to take into account the development of students' language skills. Students, in this teacher-centred model, were passive receivers of knowledge.

Consequently, some students were inattentive to the instruction and some, especially those who sat in the corner of the classroom, chatted with their partners, played with their smartphones, or even slept during class. However, all three non-key university teachers ignored those students' misbehaviours and made no effort to prevent them during the instruction.

\subsubsection{Student-Centred Model}

Compared with teachers at the non-key university, the three participating teachers at the key university adopted the student-centred model in their English classes. More specifically, these three teachers tried to introduce interesting topics relating to the teaching content into lead-in activities to stimulate students' learning interest. These three teachers warmly greeted students at the beginning of the class to bridge the psychological gap with the students and establish a good foundation for subsequent classroom interactions.

During the instruction, the three key university teachers focused on the interpretation of the whole passage, including its background, main idea, and writing style, rather than monotonous translation of the passage. More importantly, these teachers paid more attention to the development of students' critical thinking and analytical ability by providing proper guidance and/or brainstorming with mind maps to help students infer the deep meaning of the text instead of directly giving answers.

Despite the limited space, the three teachers at the key university all moved from the blackboard to interact with students. For students' correct answers, these teachers gave positive reinforcement; students' mistakes were corrected in a timely manner and students were encouraged to repeat the correct answers.

\subsection{Design of Teaching Activities}

To effectively develop the classroom instruction, all six participating teachers designed different teaching activities; these are described and analysed in detail in the following sections.

\subsubsection{Group Discussion}

Among all teaching activities, group discussion was the most common one adopted by teachers at both the key and non-key university in their English classes; however, the effect was different. The group discussion designed by the three teachers at the key university concentrated more on in-depth understanding of the teaching content and the development of students' brainstorming and critical thinking ability, which most students found stimulating. In contrast, the group discussion designed by two of the non-key university teachers was entirely focused on translation of a paragraph or text. As a result, most students showed no interest, and they tended to think about the translation version by themselves or did not do anything. The third non-key university teacher did not adopt group discussion in the whole process of teaching.

\subsubsection{Group Presentation}

Only the three key university teachers asked their students to present opinions in groups. Most students in the 
group could actively participate in the discussion and share their views with group members. After the discussion, each group had one or two presenters deliver the group's findings. Upon the completion of each group's presentation, the three teachers provided appropriate feedback and also asked the audience for additional comments.

\subsection{Classroom Language Use}

All three non-key university teachers relied on their native Chinese rather than English in most of their instruction except for some simple questions or transitional expressions, such as "What's the meaning of this sentence?" and "Let's move on to the next paragraph". Besides, these teachers allowed their students to answer questions in Chinese, limiting the promotion of students' language proficiency. In contrast, all three key university teachers used English for instruction, and only reverted to Chinese to explain difficult language points. Their students likewise used English when they answered questions, despite making mistakes. The classroom observations indicated that, overall, the non-key university teachers had lower English language proficiency in terms of pronunciation, accuracy, and fluency.

\subsection{Adoption of Teaching Aids}

All three key university teachers prepared handout materials to help students better understand the instruction. They also deployed a range of other supporting resources, such as PowerPoint, videos, audios, and pictures to stimulate students' interest and enhance teaching effectiveness. In contrast, none of the non-key university teachers used any supporting resources, exclusively relying on the textbook as their teaching resource. Notably, these practices took place regardless of the fact that the classrooms were fitted with technical equipment, such as projectors and screens.

\subsection{Peer Influences}

The observation data showed that the key university students were more likely to have positive interactions with their classmates, and were more prepared to provide support to each other. In contrast, the non-key university students were prone to be influenced by their classmates' misbehaviours and discouragement. They tended to laugh when their classmates were answering questions or sharing opinions in group discussion, in effect generating anxiety and hindering willingness to engage in classroom activities.

\section{Discussion}

Consistent with the conclusion reached by Jin and Yang (2006), as well as You and Dörnyei (2016), student participants at the key university showed a significantly higher level of achievement than their peers at the non-key university. To understand the reasons for such a difference, data collected via classroom observation were analysed quantitatively and qualitatively.

The quantitative data analyses revealed that affect - both positive and negative - was a powerful determinant of students' classroom behaviours. Overall, the key university student participants reported a higher level of positive affect, they were more engaged in class and were less likely to misbehave than their non-key university counterparts. Positive attitudes played a particularly prominent role in influencing students' classroom behaviours. Learning English has acquired considerable importance throughout the whole Chinese educational system - from primary school to university, including the two high-stakes standardised exams: the National College Entrance Examination and the CET-4 (Cheng \& Wang, 2012). Most Chinese students have a high level of awareness of the importance of English learning and are eager to attain high English proficiency. In view of this, most student participants' positive attitudes towards their English learning, at both the key and non-key university, are not altogether surprising. Negative attitudes, which were more commonly on display at the non-key university, tended to suppress students' classroom engagement and were in part responsible for their misbehaviours during class.

The relatively small number of references recorded in relation to self-esteem indicated that students at both types of school generally lacked self-esteem-with consequences for classroom engagement, particularly in orally expressing their ideas in English. Most student participants remained silent and refused to speak English during class, becoming "deaf and dumb" English learners (Cheng \& Wang, 2012, p. 28). This phenomenon was more obvious for the non-key university participants, who had lower levels of self-esteem and achievement, but a higher level of misbehaviour.

In contrast to attitudes and self-esteem, the observations did not capture much evidence relating to students' language anxiety; this situation may be partially due to the research design, which did not involve a specialised instrument for measuring anxiety, such as the Foreign Language Classroom Anxiety Scale (Horwitz et al., 1986). That said, some of the learners' behavioural and psychological characteristics documented by the study can be 
seen as indirect evidence of the presence of anxiety, such as passively answering questions and unwillingness to engage in discussions. Likewise, low self-esteem is often the source of higher anxiety in classroom interactions (Peleg, 2009).

Non-verbal engagement quite substantially exceeded verbal engagement in the observation data. Owing to socio-cultural factors, Asian EFL/ESL learners tend to keep silent in their language learning (Cheng, 2000; Liu, 2005; Liu \& Littlewood, 1997). Influenced by Confucianism, Chinese students are passive learners who fully accept their teachers' authority and are rarely prepared to think independently, let alone challenge the teacher's "wisdom" (Chang, 1993; Insull, 2001). Consistent with previous studies, listening to the teachers' instruction occupied most of the class time. The observation captured few or no references relating to student participants' actively answering or asking questions, in effect denying themselves opportunities to develop their spoken English ability. This situation was not as dire at the key university where students tended to speak English more during class and develop their critical thinking ability via verbal interactions. This outcome can be attributed to the key university students' higher levels of positive affect and English achievement and their lower level of negative affect, confirming the close relationship between affect, engagement, and achievement. The student-centred teaching models practised at the key university also positively contributed to that.

The observation recorded a large number of misbehaviours among the non-key university students. The observation data showed these participants to have significantly lower levels of achievement, positive affect, and engagement, but a higher level of negative affect than their peers at the key university. Notably, the participating teachers at the non-key university failed to take any active measures designed to suppress students' misbehaviours. To state the obvious, misbehaviours reduce teaching and learning effectiveness, and lead to lower achievement.

Considering the differences in student participants' affect, engagement, misbehaviours, and achievement, the results from the correlation analyses revealed a significant positive relationship between positive affect, engagement, and achievement; negative affect and misbehaviours, on the other hand, were strongly linked to lower engagement and lower achievement.

One very notable feature of the educational context in China is the rather large class sizes, typically running between 40 and 70 students per class. It is widely acknowledged that such class sizes are particularly unproductive for language learning. The class size itself is in part responsible for classroom misbehaviours and ineffective classroom instruction (Jin \& Cortazzi, 1998). Large class sizes likewise reduce students' capacity for meaningful interaction among each other, or interaction with their teacher, in effect promoting passive learning.

The teacher-centred teaching methods used at the non-key university were also responsible for promoting passive learning. As Freiberg (1999) argued, passive learners and compliance are valued in the teacher-centred model. All three English teachers observed at the non-key university merely focused on the instruction of grammar, sentence structure, and translation of paragraphs in their teaching, and the classroom was largely dominated by teacher talk. As passive recipients, most student participants in these classes tended to lose interest in their teachers' instruction and to lapse into one misbehaviour or another. The fact that the non-key university student participants had relatively lower levels of positive affect, engagement, and achievement but higher levels of negative affect and misbehaviours than their peers at the key university can in part be attributed to the teacher-centred teaching methods they were exposed to.

In contrast, all three teachers at the key university adopted the student-centred approach, laying the foundation for meaningful classroom interactions (Dollard \& Christensen, 1996) and the promotion of students' productive English skills. Rather than solely focusing on the instruction of basic English language knowledge, these teachers paid more attention to students' deep understanding of the textbook, critical and analytical thinking, and language communication ability. In addition, all three key university teachers deployed more effective teaching activities such as group discussion and group presentation to meet students' learning needs, promote their motivation and interest in learning. None of these were observed at the non-key university. Benefiting from this teaching approach, the key university student participants were more likely to have positive affect in their English learning, actively participate in classroom activities, avoid misbehaviour, and ultimately achieve better learning outcomes than their peers at the non-key university.

The qualitative observational analysis also found that classroom language use was another factor that influenced student participants' classroom behaviours. According to Cook (2001), the target language (TL) should predominantly be used for instruction at earlier stages of language learning in order to expose learners to the TL as much as possible, while at later stages the learners' native language (L1) can be used sparingly to check the meaning of words or sentences, explain grammar, and organise tasks. All three English teachers at the non-key 
university exclusively used their native Chinese throughout the whole instruction and allowed their students to answer questions in Chinese - presumably to reduce students' anxiety; clearly, exclusive use of the learners' L1 is not conducive to building the students' English proficiency.

These teachers' reliance on Chinese for instruction was also at least in part a reflection of their own English proficiency limitations. Compared with their peers at the key university, all three had a relatively lower level of English proficiency in terms of pronunciation, accuracy, and fluency. Teachers' English proficiency enables them to "manage classroom discourse so that it provides maximum opportunities for language learning" (Richards, 2010, p. 103). Additionally, teachers' English proficiency significantly affects their classroom language use (Canh \& Renandya, 2017), learners' acquisition of English, and learning outcomes (Nel \& Müller, 2010). Therefore, to enhance their teaching effectiveness and students' English proficiency, English teachers must continuously promote their professional skills.

The observational data also showed that the differential deployment of teaching aids across the two types of school was also related to student participants' different levels of affect, engagement, misbehaviours, and achievement. In addition to the adoption of advanced electronic equipment, all three key university teachers prepared handout materials for their students' better understanding and analysis of the textbook. Overall, participating teachers' preparation and investment for their classes partially accounted for students' different levels of affect, engagement, misbehaviours, and achievement.

Lastly, student participants' different levels of affect, engagement, misbehaviours, and achievement could be understood from the perspective of peer pressure. Research has demonstrated that learners benefit when they receive positive reinforcement from their peers (Wentzel \& Watkins, 2002; Wood \& O'Malley, 1996) and would also be negatively affected by their peers' misconduct (Clasen \& Brown, 1987). The observation data showed that peer influences at the non-key university were predominantly negative, including peer discouragement and peer misbehaviour. This unavoidably contributed to lowering the non-key university student participants' positive affect, active engagement, and achievement in comparison with their key university counterparts.

\section{Conclusion}

The current study furthers our understanding of the relationship between EFL learners' affect, engagement, misbehaviours, and achievement in a language classroom context. Our findings showed that type of school was a powerful factor influencing student participants' affect, engagement, misbehaviours, and achievement. Student participants' positive affect was significantly and positively connected with engagement and achievement but significantly and negatively related to misbehaviours. In contrast, student participants' negative affect had negative relationships with engagement and achievement but a positive correlation with misbehaviours. Although correlation analyses cannot reveal causal relationships among variables, they can give us a good sense of what these relationships are like. These findings have clear implications for teachers and teaching. Emotional regulation of learners' affect is essential for enhancing their engagement and achievement. Teachers should deploy classroom activities designed to promote learners' classroom engagement, especially their active verbal participation; otherwise the development of learners' L2 communication skills would be next to impossible. More effort should go into the management of classroom misbehaviours to minimise their disruptive effects on teaching and learning.

Learners' affect, engagement, and achievement are also a function of the classroom environment. Positive and constructive relationships between teachers and learners, and also between the learners themselves, can strongly contribute to teaching and learning outcomes.

\section{Acknowledgements}

The authors would like to thank all participants for their participation in this study and anonymous reviewers for their constructive comments.

\section{References}

Arnold, J., \& Brown, H. D. (1999). A map of the terrain. In J. Arnold (Ed.), Affect in language learning (pp. 1-24). Cambridge University Press.

Astin, A. W. (1984). Student involvement: A developmental theory for higher education. Journal of College Student Personnel, 25(4), 297-308.

Bailey, K. M. (2001). Observation. In R. Carter \& D. Nunan (Eds.), The Cambridge guide to teaching English to speakers of other languages (pp. 114-119). Cambridge University Press. https://doi.org/10.1017/CBO9780511667206.017 
Canh, L., \& Renandya, W. A. (2017). Teachers' English proficiency and classroom language use: A conversation analysis study. RELC Journal, 48(1), 67-81. https://doi.org/10.1177/0033688217690935

Carini, R., Kuh, G., \& Klein, S. (2006). Student engagement and student learning: Testing the linkages. Research in Higher Education, 47(1), 1-32. https://doi.org/10.1007/s11162-005-8150-9

Chang, J. (1993). Chinese Speakers. In M. Swan \& B. Smith (Eds.), Learner English (pp. 224-237). Cambridge University Press.

Cheng, A., \& Wang, Q. (2012). English language teaching in higher education in China: A historical and social overview. In J. Ruan \& C. B. Leung (Eds.), Perspectives on teaching and learning English literacy in China (pp. 19-33). Springer. https://doi.org/10.1007/978-94-007-4994-8_2

Cheng, X. (2000). Asian students' reticence revisited. System, 28(3), 435-446. https://doi.org/10.1016/S0346-251X(00)00015-4

Clasen, D. R., \& Brown, B. B. (1987). Understanding peer pressure in middle school. Middle School Research Selected Studies, 12(1), 65-75. https://doi.org/10.1080/08851700.1987.11670280

Clément, R., Dörnyei, Z., \& Noels, K. (1994). Motivation, self-confidence, and group cohesion in the foreign language classroom. Language Learning, 44(3), 417-448. https://doi.org/10.1111/j.1467-1770.1994.tb01113.x

Clore, G. L., Wyer, R. S., Dienes, B., Gasper, K., Gohm, C., \& Isbell, L. (2001). Affective feelings as feedback: Some cognitive consequences. In L. L. Martin \& G. L. Clore (Eds.), Theories of mood and cognition: A user's handbook (pp. 27-62). Lawrence Erlbaum.

Cook, V. (2001). Using the first language in the classroom. The Canadian Language Review, 57(3), 399-423. https://doi.org/10.3138/cmlr.57.3.402

Croll, P. (1986). Systematic classroom observation. Falmer Press.

Davidson, R. J. (1994). On emotion, mood and related affective constructs. In P. Ekman \& R. J. Davidson (Eds.), The nature of emotion (pp. 51-55). Oxford University Press.

Debreli, E., \& Ishanova, I. (2019). Foreign language classroom management: Types of student misbehaviour and strategies adapted by the teachers in handling disruptive behaviour. Cogent Education, 6(1), 1-22. https://doi.org/10.1080/2331186X.2019.1648629

Deniz, S. O., \& Chockalingam, V. (2003). The big-5 personality and counterproductive behaviours. In S. Abraham, S. Shmuel \& K. Meni (Eds.), Misbehaviour and dysfunctional attitudes in organizations (pp. 211-249). Palgrave Macmillan. https://doi.org/10.1057/9780230288829_12

Dollard, N., \& Christensen, L. (1996). Constructive classroom management. Focus on Exceptional Children, 29(2), 1-24. https://doi.org/10.17161/foec.v29i2.6860

Dörnyei, Z. (1994). Understanding L2 motivation: On with the challenge! The Modern Language Journal, 78(4), 515-523. https://doi.org/10.1111/j.1540-4781.1994.tb02071.x

Dörnyei, Z. (2005). The psychology of the language learner: Individual differences in second language acquisition. Lawrence Erlbaum.

Dörnyei, Z., \& Clément, R. (2001). Motivational characteristics of learning different target languages: Results of a nationwide survey. In Z. Dörnyei \& R. Schmidt (Eds.), Motivation and second language acquisition (pp. 399-432). The University of Hawaii, Second Language Teaching \& Curriculum Centre.

Flanders, N. (1970). Analyzing teaching behavior. Addison-Wesley.

Fredricks, J. A. (2011). Engagement in school and out-of-school contexts: A multidimensional view of engagement. Theory into Practice, 50(4), 327-335. https://doi.org/10.1080/00405841.2011.607401

Freiberg, H. J. (1999). Beyond behaviorism: Changing the classroom management paradigm. Allyn \& Bacon.

Gardner, R. C. (1985). Social psychology and second language learning: The role of attitudes and motivation. Edward Arnold.

Gardner, R. C., \& MacIntyre, P. D. (1993). On the measurement of affective variables in second language learning. Language Learning, 43(2), 157-194. https://doi.org/10.1111/j.1467-1770.1992.tb00714.x

Genesee, F., Lindholm-Leary, K., Saunders, W., \& Christian, D. (2005). English language learners in U.S. schools: An overview of research findings. Journal of Education for Students Placed at Risk, 10(4), 
363-386. https://doi.org/10.1207/s15327671espr1004_2

Habrat, A. (2018). The role of self-esteem in foreign language learning and teaching. Springer. https://doi.org/10.1007/978-3-319-75283-9

Horwitz, E. K. (2001). Language anxiety and achievement. Annual Review of Applied Linguistics, 21(1), 112-127. https://doi.org/10.1017/S0267190501000071

Horwitz, E. K., Horwitz, M. B., \& Cope, J. A. (1986). Foreign language classroom anxiety. The Modern Language Journal, 72(2), 125-132. https://doi.org/10.1111/j.1540-4781.1986.tb05256.x

Insull, B. (2001). Encouraging student voices in a Chinese classroom. English Teaching Forum, 39(4), 34-37.

Jin, L., \& Cortazzi, M. (1998). Dimensions of dialogue: Large classes in China. International Journal of Educational Research, 29(8), 739-761. https://doi.org/10.1016/S0883-0355(98)00061-5

Jin, Y., \& Yang, H. Z. (2006). The English proficiency of college and university students in China: As reflected in the CET. Language, Culture and Curriculum, 19(1), 21-36. https://doi.org/10.1080/07908310608668752

Khoo, A. C. E., \& Oakes, P. J. (2003). School misbehaviour as a coping strategy for negative social comparison and academic failure. Social Psychology of Education, 6(4), 255-281. https://doi.org/10.1023/A:1025678514399

Liu, M. H. (2005). Reticence in oral English language classrooms: A case study in China. TESL Reporter, 38(1), $1-16$.

Liu, M. H., \& Zhang, W. (2008). An exploration of Chinese EFL learners' foreign language anxiety, personality and self-esteem. Journal of Applied Linguistics, 5(2), 181-203. https://doi.org/10.1558/japl.v5i2.181

Liu, N. F., \& Littlewood, W. (1997). Why do many students appear reluctant to participate in classroom learning discourse? System, 25(3), 371-384. https://doi.org/10.1016/S0346-251X(97)00029-8

Nel, N., \& Müller, H. (2010). The impact of teachers' limited English proficiency on English second language learners in South African schools. South African Journal of Education, 30(4), 635-650. https://doi.org/10.15700/saje.v30n4a393

Nunan, D. (1992). Research methods in language learning. Cambridge University Press.

Onwuegbuzie, A. J., Bailey, P., \& Daley, C. E. (2000). Cognitive, affective, personality, and demographic predictors of foreign-language achievement. Journal of Educational Research, 94(1), 3-15. https://doi.org/10.1080/00220670009598738

Oxford, R. L. (1990). Language learning strategies: What every teacher should know. Newbury House Publisher.

Peleg, O. (2009). Test anxiety, academic achievement, and self-esteem among Arab adolescents with and without learning disabilities. Learning Disability Quarterly, 32(1), 11-20. https://doi.org/10.2307/25474659

Richards, J. C. (2010). Competence and performance in language teaching. RELC Journal, 41(2), 101-122. https://doi.org/10.1177/0033688210372953

Ritson, R. J., Smith, R. J., \& Twa, H. I. (1982). Student and teacher interaction analysis: A comparison of activities, age groups and sex of the students in physical education. Journal of Teaching in Physical Education, 1(2), 15-25. https://doi.org/10.1123/jtpe.1.2.15

Rosenberg, E. L. (1998). Levels of analysis and the organization of affect. Review of General Psychology, 2(3), 247-270. https://doi.org/10.1037/1089-2680.2.3.247

Ryan, R. M., \& Deci, E. L. (2000). Self-determination theory and the facilitation of intrinsic motivation, social $\begin{array}{llll}\text { development, and } \quad \text { american } & \text { Psychologist, }\end{array}$ https://doi.org/10.1037/0003-066X.55.1.68

Schwarz, N., \& Clore, G. L. (1996). Feelings and phenomenal experiences. In E. T. Higgins \& A. W. Kruglanski (Eds.), Social psychology: Handbook of basic principles (pp. 433-465). Guilford.

Simpson, E. S. C., \& Weiner, J. A. (Eds.). (1989). The Oxford English dictionary. Clarendon Press.

Türnüklü, A., \& Galton, M. (2001). Students' misbehaviours in Turkish and English primary classrooms. Educational Studies, 27(3), 291-305. https://doi.org/10.1080/03055690120076574

Wentzel, K. R., \& Watkins, D. E. (2002). Peer relationships and collaborative learning as contexts for academic enablers. School Psychology Review, 31(3), 366-377. https://doi.org/10.1080/02796015.2002.12086161 
Wood, D., \& O’Malley, C. (1996). Collaborative learning between peers. Educational Psychology in Practice, 11(4), 4-9. https://doi.org/10.1080/0266736960110402

Wragg, E. C. (2012). An introduction to classroom observation. Routledge Falmer. https://doi.org/10.4324/9780203357279

\section{Copyrights}

Copyright for this article is retained by the author, with first publication rights granted to the journal.

This is an open-access article distributed under the terms and conditions of the Creative Commons Attribution license (http://creativecommons.org/licenses/by/4.0/). 